\title{
The optimization of acid hydrolysis on bioethanol production from durian peel waste (Durio zibethinus murr)
}

\author{
Shanta Noventhya Ginting ${ }^{1^{*}}$, Epi Kristina Simanullang ${ }^{1}$, Lindu Parningotan Simanullang ${ }^{2}$, \\ Bajoka Nainggolan ${ }^{1}$, Saronom Silaban ${ }^{1}$ \\ 'Department of Chemistry, Universitas Negeri Medan, Medan 20221, Indonesia \\ ${ }^{2}$ Department of Physics, Universitas Negeri Medan, Medan 2022l, Indonesia
}

\begin{abstract}
:
The dependence on fossil fuels is a big problem and needs an urgent solution. One of the steps taken is the utilization of bioethanol "lignocellulose". This research uses natural material with high lignocellulose content that is durian peel waste and aims to make durian peel waste as raw material of bioethanol production with variation of $\mathrm{H}_{2} \mathrm{SO}_{4}$ concentration, temperature, and acid hydrolysis time. The variable used is $\mathrm{H}_{2} \mathrm{SO}_{4}$ concentration of $1 \%, 3 \%$, and $5 \%$; temperature of $100^{\circ} \mathrm{C}, 120^{\circ} \mathrm{C}$, and $140^{\circ} \mathrm{C}$; and time of 120 minutes, 150 minutes, and 180 minutes. From the analysis, the highest bioethanol purity was obtained at $99.81 \%$ at $100^{\circ} \mathrm{C}$ and hydrolysis time at 120 minutes.
\end{abstract}

Keywords:

acid hydrolysis; bioethanol; durian peel waste; optimization

\section{Introduction}

National energy needs sustained approximately $51.66 \%$ of petroleum, natural gas $28.57 \%$ and coal $15.34 \%$. Petroleum reserve would be exhausted around 12 years, gas 30 years and coal can still be used up to 70 years into the future. This dependence on fossil fuels is a big problem and needs urgent solutions. One step solution is utilize lignocellulosic bioethanol (Trisakti et al., 2015). Lignocellulosic materials are biomass derived from plants with main components lignin, cellulose, and hemicellulose. Natural material cellulose can be used as a source of raw material in the production of bioethanol. Bioethanol has several advantages over other alternative energy. Ethanol has a high oxygen content (35\%) so it burns more perfectly, worth the higher octane (118), and it is environmentally friendly because it contains lower CO gas emissions $19-25 \%$.

One of the natural material with a high content of lignocellulose is durian peel waste. Durian production in Indonesia is relatively abundant. Badan Pusat Statistik (2004), showed that durian production is increasing every year.

\footnotetext{
* Corresponding author.

shantanoventhya27@gmail.com

doi: https://doi.org/10.24114/jpkim.v10i2.10917
}

Of the durian fruit is 57 percent of the peel, so that worry becomes a waste if not utilized. North Sumatra annually produces 332.712 tonnes of durian peel, which will have an impact on the environment and may cause flooding if the durian peel waste is not empowered.

Durian is a tropical plant whose name comes from Southeast Asia, as well as the name of the fruit that can be eaten. The name is taken from a characteristic peel of the fruit is hard and sharp grooved to resemble thorns. its most popular title is "king of all fruits", and durian is a controversial fruit. Although many people like it, some others are sick of its scent. Durian peel has a chemical composition (Jana et al., 2010) as in Table 1.

Bioethanol is basically ethanol produced from biomass (McMillan, 1994). O'Leary et al. (2004), Saccharomyces cerevisiae is the yeast used in the fermentation of alcohol. Saccharomyces cerevisiae has several advantages over other microbes that can form the alcohol. Based on the above, by looking at the potential of North Sumatra, where the existence of durian peel waste materials are very much available and has not been utilized optimally, becomes very potential to produce bioethanol from durian peel waste using acid hydrolysis optimization.

Materials and Methods 


\section{Tools and materials}

The tools used in this research is a stirring rod, beakerglass, a bottle of distilled water, cup petridish, flask, beakers, volumetric flask, grinding machine, oven, bath, ph meter, pipette, knives, set of distillation equipment, set of hydrolysis equipment, spatula, cutting board, thermometer, digital scales. While the materials used in this research is distilled water, salt, $\mathrm{H}_{2} \mathrm{SO}_{4}$, durian peel, $\mathrm{NaOH}$, Saccaromycess cereviceae.

\section{The research procedure}

The research procedure can be seen in Fig 1.

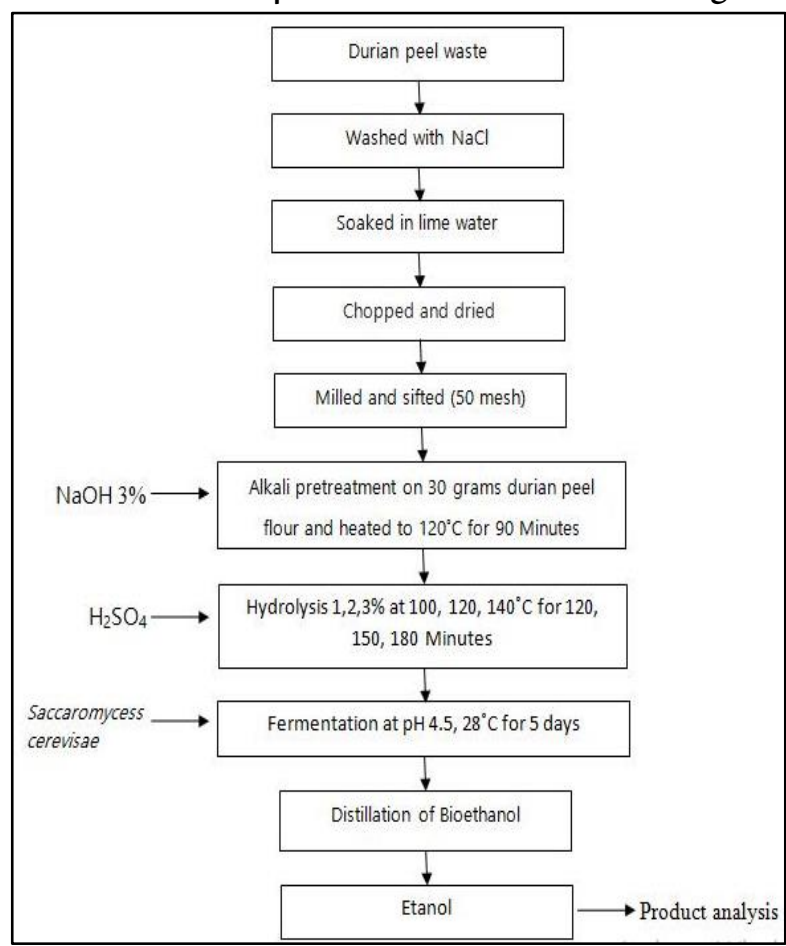

Fig 1. The flow chart of bioethanol production from durian peel waste.

\section{Product analysis}

Determination of the amount of ethanol $(\mathrm{mL})$ : distillate distilled accommodated (bioethanol) to be measured is by using a measuring cup, and then the volume is recorded for each treatment (Pusat Penelitian Sumberdaya Hayati dan Bioteknologi, 2010).

Table 1

Durian peel composition (Jana et al., 2010)

\begin{tabular}{cc}
\hline Compound & Percentage (\%) \\
\hline Hemicellulose & 13.09 \\
Cellulose & 60.45 \\
Lignin & 15.45 \\
Ash & 4.35 \\
\hline
\end{tabular}

Analysis of bioethanol density $(\mathrm{g} / \mathrm{mL})$ : ten $\mathrm{ml}$ pycnometer instrument used to measure the concentration of ethanol is dried in an oven at a temperature of $100^{\circ} \mathrm{C}$. for 30 minutes then cool to room temperature; weigh the empty pycnometer $10 \mathrm{ml}$ using an analytical balance and note the weight; the pycnometer filled with distilled water and then weighed with an analytical balance and record the weight; pycnometer Preheat an oven at $100^{\circ} \mathrm{C}$ for 30 minutes tempaeratur then cool to room temperature; enter distillate samples into the pycnometer until there are no air bubbles; weigh the pycnometer containing distillate samples using an analytical balance and record the weight; record the room temperature at the time of weighing; and then density is calculated using the formula (Bustan et al., 2013):

$\rho=\frac{\text { (Wpycno contain sample-Wpycno blank) }}{\text { Vpycno }}$

Form 1. Density

Information

$\rho=$ densitas

$V=$ pycnometer volume

Specific analysis grafity (sg) and APl grafity (G): density of bioethanol has been determined in the previous procedure, and specific grafity value calculated for each sample by using the following equation:

$s g=\frac{\text { densitas sampel }\left(\mathrm{kg} / \mathrm{m}^{3}\right)}{\text { densitas air }\left(\mathrm{kg} / \mathrm{m}^{3}\right)}$

Form 2. Spesific grafity

APl gravity value calculated for each sample by the following equation:

$$
G=\frac{141,5}{s g}-131,5
$$

Then note all prices on the specific gravity and API gravity for each treatment (Pusat Penelitian Sumberdaya Hayati dan Bioteknologi, 2010).

Analysis of calorific value (NK): the calorific value calculated using the equation:

$N K=\frac{2,2046226}{3,9673727} \times(18,650+40 \times(G-10)) \mathrm{kkal} / \mathrm{kg}$

Form 3. Calorific value

Note all calorific values obtained for each treatment (Pusat Penelitian Hayati dan Teknologi, 2010). Bioethanol analysis method with gravity density values obtained previously in the the conversion density - concentration of ethanol in Table 2 (Perry et al., 1999). 
Table 2

The conversion density - concentration of ethanol (Perry et al., 1999).

\begin{tabular}{|c|c|c|c|}
\hline $\begin{array}{l}\text { The } \\
\text { Concentration } \\
\text { Of Ethanol }\end{array}$ & $\begin{array}{c}\text { The } \\
\text { Density } \\
\text { of } \\
\text { Ethanol } \\
\text { (on } \\
30^{\circ} \mathrm{C} \text { ) }\end{array}$ & $\begin{array}{c}\text { The } \\
\text { Concentration } \\
\text { Of Ethanol }\end{array}$ & $\begin{array}{c}\text { The } \\
\text { Density } \\
\text { of } \\
\text { Ethanol }\end{array}$ \\
\hline 0 & 0.99568 & 25 & 0.95607 \\
\hline 1 & 0.99379 & 26 & 0.95442 \\
\hline 2 & 0.99194 & 27 & 0.95272 \\
\hline 3 & 0.99014 & 28 & 0.95098 \\
\hline 4 & 0.98839 & 29 & 0.94922 \\
\hline 5 & 0.98670 & 30 & 0.94741 \\
\hline 6 & 0.98507 & 31 & 0.94557 \\
\hline 7 & 0.98347 & 32 & 0.94370 \\
\hline 8 & 0.98189 & 33 & 0.94180 \\
\hline 9 & 0.98031 & 34 & 0.93986 \\
\hline 10 & 0.97875 & 35 & 0.93790 \\
\hline 11 & 0.97723 & 36 & 0.93591 \\
\hline 12 & 0.97723 & 37 & 0.93390 \\
\hline 13 & 0.97424 & 38 & 0.93186 \\
\hline 14 & 0.97278 & 39 & 0.92979 \\
\hline 15 & $\begin{array}{c}00.9713 \\
3\end{array}$ & 40 & 0.92770 \\
\hline 16 & 0.96990 & 41 & 0.92558 \\
\hline 17 & 0.96844 & 42 & 0.92344 \\
\hline 18 & 0.96697 & 43 & 0.92128 \\
\hline 19 & 0.96547 & 44 & 0.91910 \\
\hline 20 & 0.96395 & 45 & 0.91692 \\
\hline 21 & 0.96242 & 46 & 0.91472 \\
\hline 22 & 0.96087 & 47 & 0.91250 \\
\hline 23 & 0.95929 & 48 & 0.91028 \\
\hline 24 & 0.95769 & 49 & 0.90805 \\
\hline
\end{tabular}

\section{Results}

This research uses durian peel waste as the main raw material in the production of bioethanol by giving optimization treatment on acid hydrolysis process. Hydrolysis process aims to break the bond and removes lignin and hemicellulose and damaging the crystal structure of cellulose into simple sugars (Sun \& Cheng, 2002). The results of the study are shown in Fig 2, Fig 3, Fig 4, Fig 5, Fig 6, Fig 7, Fig 8, and Fig 9.

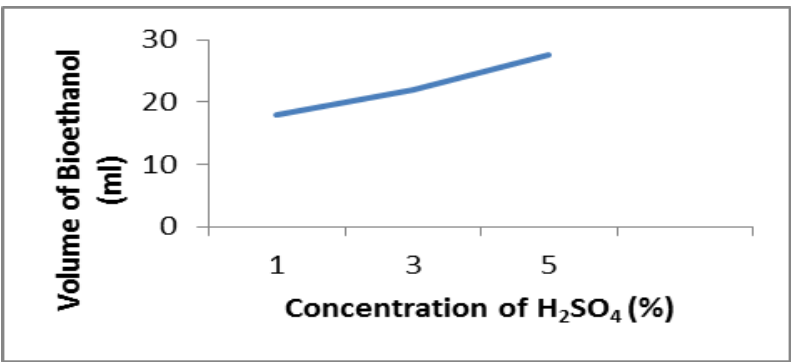

Fig 2. The effect of $\mathrm{H}_{2} \mathrm{SO}_{4}$ concentration to the amount of bioethanol.

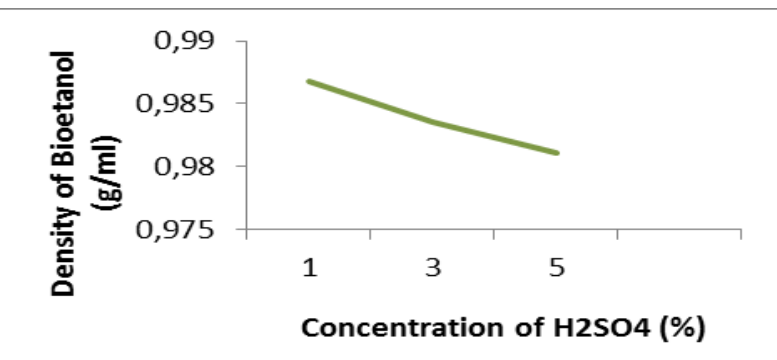

Fig 3. The effect of $\mathrm{H}_{2} \mathrm{SO}_{4}$ concentration on the density of bioethanol.

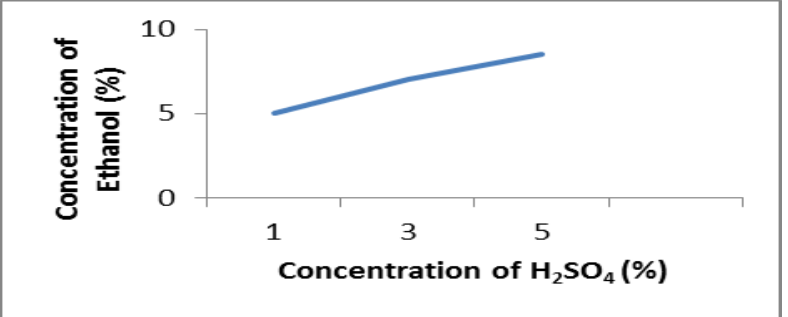

Fig 4. The effect of $\mathrm{H}_{2} \mathrm{SO}_{4}$ concentration on the concentration of ethanol.

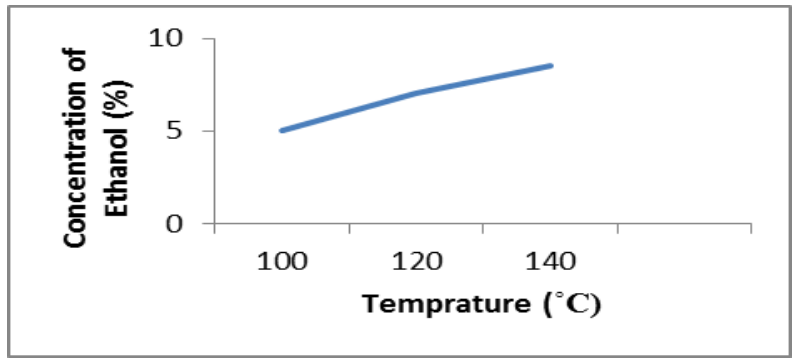

Fig 5. The effect of acid hydrolysis temprature on the concentrationof ethanol.

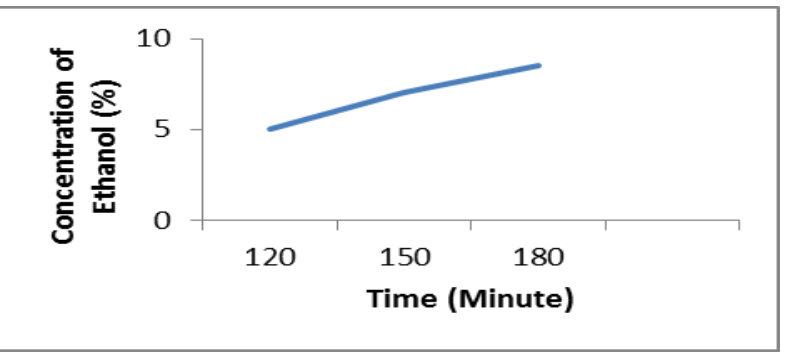

Fig 6. The effect of acid hydrolysis time on the concentration of ethanol.

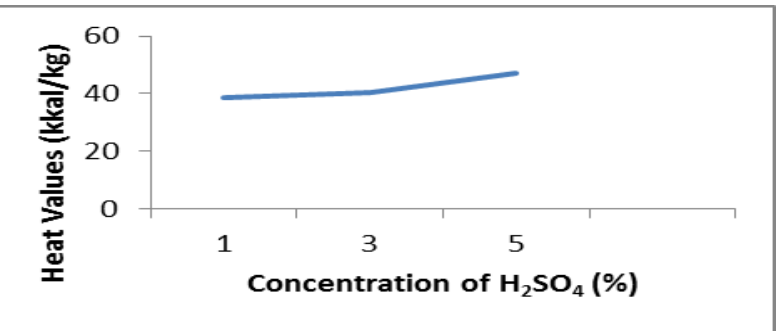

Fig 7. The effect of $\mathrm{H}_{2} \mathrm{SO}_{4}$ concentration on the heat values of bioethanol.

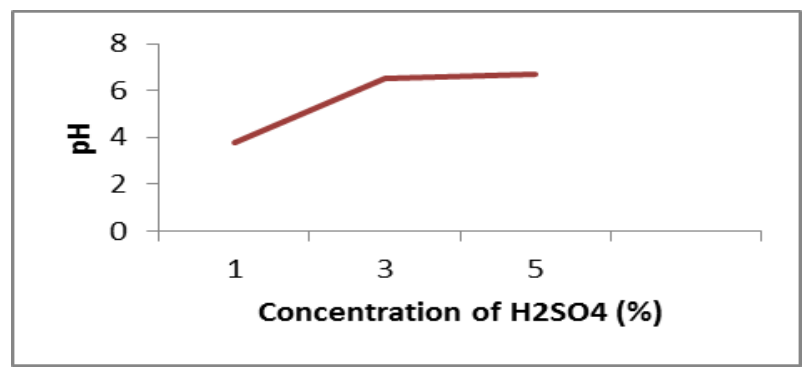

Fig 8. The effect of $\mathrm{H}_{2} \mathrm{SO}_{4}$ concentration on the $\mathrm{pH}$ of bioethanol. 


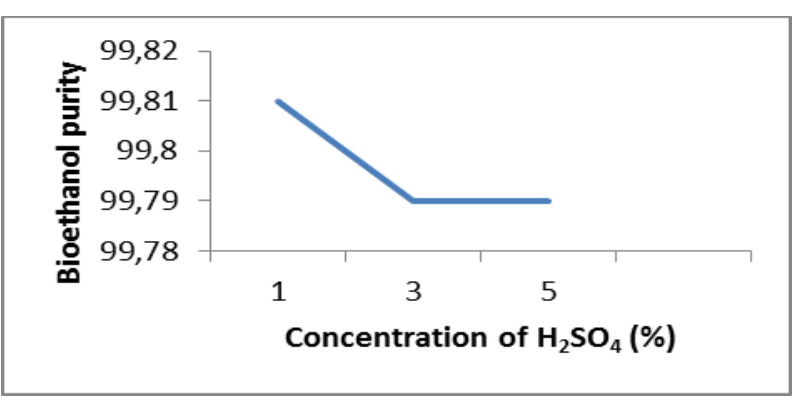

Fig 9. Bioethanol purity was analyzed using GC-MS.

\section{Discussion}

The research was conducted by varying the concentration of $\mathrm{H}_{2} \mathrm{SO}_{4}$, temperature and time in the process of acid hydrolysis. The effect of $\mathrm{H}_{2} \mathrm{SO}_{4}$ concentration to the amount of bioethanol in Fig 2 can be seen that the greater the concentration of $\mathrm{H}_{2} \mathrm{SO}_{4}$ used, the more also the volume of ethanol produced. In this picture, it appears that the optimum point of $\mathrm{H}_{2} \mathrm{SO}_{4}$ concentration which produces bioethanol volume is at most $5 \% \mathrm{H}_{2} \mathrm{SO}_{4}$ concentration is as much as $27.5 \mathrm{ml}$.

The effect of $\mathrm{H}_{2} \mathrm{SO}_{4}$ concentration on the density of bioethanol in Fig 3 can be seen that the density of bioethanol obtained for each of the acid concentration has exceeded density requirement $\mathrm{SNl}$ bioethanol that is equal to $0.8215 \mathrm{~g} / \mathrm{mL}$ (Badan standar nasional, 2009). This is because the research used simple distillation and less scrupulous in maintaining the stability tempratur so that steam coming out not only ethanol but has been mixed with water. The effect of $\mathrm{H}_{2} \mathrm{SO}_{4}$ concentration on the concentration of ethanol in Fig 4 can be seen that that the highest ethanol content obtained from the hydrolysis process by using $\mathrm{H}_{2} \mathrm{SO}_{4}$ concentration of $5 \%$ resulted in $8.5 \%$ ethanol and also concluded that the levels of glucose increases with increasing concentration of acid hydrolysis where the optimum concentration for which a concentration of $5 \% \mathrm{H}_{2} \mathrm{SO}_{4}$.

Advantages of the use of a strong acid at low concentrations is no longer necessary acid recovery and the absence of acid ion lost in the process (Iranmahboob et al., 2002). The effect of acid hydrolysis temprature on the concentration of ethanol in Fig 5 can be seen that the highest ethanol content obtained when the hydrolysis temperature of $140^{\circ} \mathrm{C}$. The effect of acid hydrolysis time on the concentration of ethanol in Fig 6 can be seen that the longer the process of acid hydrolysis, the higher concentration of ethanol produced. In this research, obtained the highest ethanol content at $180^{\circ} \mathrm{C}$. If it is caused by the longer the process of hydrolysis, the more time for the ongoing breakdown of the bond and removes lignin and hemicellulose and damaging the crystal structure of cellulose into simple sugars, so that the concentration of ethanol increase.

The effect of $\mathrm{H}_{2} \mathrm{SO}_{4}$ concentration on the heat values of bioethanol in Fig 7 can be seen that the highest heat values is obtained at a concentration of $5 \% \mathrm{H}_{2} \mathrm{SO}_{4}$ in the amount of $46.972 \mathrm{kkal} / \mathrm{kg}$. The heat values obtained in the bioethanol from durian peel is still very low, because the heat values of bioethanol SNI requirement is a maximum of $5000 \mathrm{kkal} / \mathrm{kg}$ (Badan standar nasional, 2009).

The effect of $\mathrm{H}_{2} \mathrm{SO}_{4}$ concentration on the $\mathrm{pH}$ of bioethanol in Fig 8 can be seen that the $\mathrm{pH}$ of bioethanol obtained for $3 \% \mathrm{H}_{2} \mathrm{SO}_{4}$ concentration is 6.5 and $5 \% \mathrm{H}_{2} \mathrm{SO}_{4}$ at $\mathrm{pH} 6.7$ has been qualified ISN bioethanol in the amount of 6.5 to 9.0. While the $\mathrm{pH}$ of bioethanol for $\mathrm{H}_{2} \mathrm{SO}_{4}$ concentration of $1 \%$ is equal to 3.8 , the $\mathrm{pH}$ does not meet the qualified of SNI bioethanol. The bioethanol purity was analyzed using GC-MS in Fig 9 can be seen that the highest bioethanol purity is at $99,81 \%$ using $\mathrm{H}_{2} \mathrm{SO}_{4} 1 \%$. There is a very large difference in results between analysis using picnometer and GC, This is because of analysis with picnometer using compound density, whereas in GC analysis, only ethanol detected to be measured ethanol (Novia et al., 2017). Bioethanol which can be used as fuel is bioethanol with a purity of 95\% (Irhamni et al., 2017). Irhamni et al. (2017), in their research concluded that bioethanol of durian peel waste with Saccharification and Liquification method obtains the highest bioethanol purity at $96.99 \%$. In this research, the highest bioethanol purity obtained is at $99.81 \%$, so it can be concluded that bioethanol from durian peel waste is potentially used as fuel.

\section{Conclusion}

The conclusion of this research are: The optimum amount of bioethanol obtained in this research is $27.5 \mathrm{ml}$ with a density of $0.9811 \mathrm{~g} / \mathrm{ml}$ at a hydrolysis temperature of $140^{\circ} \mathrm{C}$ with hydrolysis time of 180 minutes. The highest concentration of ethanol obtained amounted to $8.5 \%$ at a concentration of $5 \% \mathrm{H}_{2} \mathrm{SO}_{4}$. The optimum heat values is $46.972 \mathrm{kkal} / \mathrm{kg}$ and the greater the concentration of $\mathrm{H}_{2} \mathrm{SO}_{4}$ and the longer time the acid hydrolysis of the resulting ethanol content increases. The bioethanol purity was analyzed using GC-MS in figure 10 can be seen that the highest bioethanol purity is at $99,81 \%$ using $\mathrm{H}_{2} \mathrm{SO}_{4}$ $1 \%$. There is a very large difference in results between analysis using picnometer and GC.

Acknowledgments 
Acknowledgments to Kemenristekdikti who has provided PKMP research fund by letter of agreement number: 1020/B3.1/KM/2018.

\section{References}

Badan Standar Nasional. (2009). Etanol vegetatif, SNI 3565. Jakarta.

Bustan, D., Royen, H. \& Manurung, E. W. (2013). Pembuatan etanol dari tepung ubi kayu dengan menggunakan metode hidrolisa. Jurnal Teknik Kimia, 19(3), 9-14.

Indartono, Y. (2005). Bioethanol, alternatif energi terbarukan: Kajian prestasi mesin dan implementasi di lapangan. Fisika, LIPI.

Iranmahboob, J., Nadim, F. \& Monemi, S. (2002). Optimizing acid-hydrolysis: a critical step for production of ethanol from mixed wood chips. Biomass and Bioenergy, 22(5), 401-404.

Irhamni, I., Diana, D., Saudah, S., Mulyati, D., Suzanni, M. A. \& Ernilasari, E. (2017). Produksi bioetanol dari limbah kulit durian. SemdiUnaya, 1, 281-288.

Jana L., H. Oktavia. \& Wulandari D. (2010). The using of durian peels trashes as a potential source of fiber to fiber to prevent colorectal cancer. Faculty of Medicine, Sebelas Maret University. Surakarta. ssf terhadap etanol pembuatan bioetanol dari sekam padi. Jurnal Teknik Kimia, 23(1), 19-27.

O'leary, V. S., Green, R., Sullivan, B. C. \& Holsinger, V. H. (1977). Alcohol production by selected yeast strains in lactase-hydrolyzed acid whey. Biotechnology and Bioengineering, 19(7), 1019-1035.

Perry, R. H., Green, D. \& MaloneY, J. (1999). Psychrometry, evaporative cooling, and solids drying. Perry's Chemical Engineers' Handbook, Eds.; McGraw-Hill: Nova York, 12-52.

Pusat Penelitian Sumberdaya Hayati dan Bioteknologi. (2010). Prosedur produksi bioethanol, laboratorium BIORIN, Bogor Agricultural University. Bogor.

Sun, Y., \& Cheng, J. (2002). Hydrolysis of lignocellulosic materials for ethanol production: a review. Bioresource technology, 83(1), 1-11.

Trisakti, B., \& Silitonga, Y. Irvan. 2015. Pembuatan bioetanol dari tepung ampas tebu melalui proses hidrolisis termal dan fermentasi serta recycle vinasse (Pengaruh konsentrasi tepung ampas tebu, suhu dan waktu hidrolisis). Jurnal Teknik Kimia USU, 4(3), 17-22.

Lubis, R. (2013). Product Innovation from Durian Peel Waste. Seminar in the Fisip Hall. UMA University of Medan.

McMillan, J. D. (1994). Pretreatment of lignocellulosic biomass. In ACS symposium series (USA).

Novia, N., Wijaya, D. \& Yanti, P. (2017). Pengaruh waktu delignifikasi terhadap lignin dan waktu 